\title{
Paenibacillus durus (Collins et al. 1994, formerly Clostridium durum Smith and Cato 1974) has priority over Paenibacillus azotofixans (Seldin et al. 1984). Opinion 73
}

\author{
Judicial Commission of the International Committee on Systematics of \\ Prokaryotes
}

Correspondence

Hans G. Trüper

trueper@uni-bonn.de
The Judicial Commission of the International Committee on Systematics of Prokaryotes decided that the name Paenibacillus durus has priority over Paenibacillus azotofixans, and that the latter is a later synonym of the former. The type strain is therefore strain ATCC 27763 (=DSM 1735).
Clostridium durum was described by Smith \& Cato (1974) and the name was validly published by inclusion in the Approved Lists of Bacterial Names (Skerman et al., 1980). Seldin et al. (1984) described a nitrogen-fixing sporeforming bacterium and named it Bacillus azotofixans. Ten years later, Ash et al. (1994) proposed that Bacillus azotofixans be transferred to the newly established genus Paenibacillus, and Collins et al. (1994) proposed that Clostridium durum be transferred to the same new genus as Paenibacillus durum [sic]. A thorough comparison of two strains of Paenibacillus durum [sic] and five strains of Paenibacillus azotofixans by Rosado et al. (1997) showed convincingly that all strains belonged to the same species. Rosado et al. (1997) then united the two species under the name Paenibacillus azotofixans, a step that clearly violated Rule 23a of the Bacteriological Code (1990 Revision) (Lapage et al., 1992).

This irregularity was detected by Logan et al. (1998), who - emphasizing that Paenibacillus durum [sic] deserves priority over Paenibacillus azotofixans - submitted a respective Request for an Opinion.

The Judicial Commission adjusted the gender of the specific epithet to durus (masculine) and decided that the name Paenibacillus durus has priority over Paenibacillus azotofixans; furthermore, it was decided that the type strain of Paenibacillus durus is VPI 6563 (=ATCC $27763=$ DSM 1735), not P3L5 (=ATCC 35681). The name Paenibacillus azotofixans is a later synonym of Paenibacillus durus. The argument that the specific epithet azotofixans would be more informative than the specific epithet durus cannot be taken into consideration when the priority is clear.

\section{References}

Ash, C., Priest, F. G. \& Collins, M. D. (1993). Molecular identification of rRNA group 3 bacilli (Ash, Farrow, Wallbanks and Collins) using a PCR probe test. Antonie van Leeuwenhoek 64, 253-260.

Collins, M. D., Lawson, P. A., Willems, A., Cordoba, J. J., FernandezGarayzabal, J., Garcia, P., Cai, J., Hippe, H. \& Farrow, J. A. E. (1994). The phylogeny of the genus Clostridium: proposal of five new genera and eleven new species combinations. Int J Syst Bacteriol 44, 812-826.

Lapage, S. P., Sneath, P. H. A., Lessel, E. F., Skerman, V. B. D., Seeliger, H. P. R. \& Clark, W. A. (editors) (1992). International Code of Nomenclature of Bacteria (1990 Revision). Bacteriological Code. Washington, DC: American Society for Microbiology.

Logan, N. A., Heyndrickx, M., Berkeley, R. C. W. \& De Vos, P. (1998). Paenibacillus azotofixans (Seldin et al. 1984) Ash et al. 1995 does not have priority over Paenibacillus durum (Smith and Cato 1974) Collins et al. 1994.: Request for an Opinion. Int J Syst Bacteriol 48, 325-326.

Rosado, A. S., van Elsas, J. D. \& Seldin, L. (1997). Reclassification of Paenibacillus durum (formerly Clostridium durum Smith and Cato (1974) Collins et al. 1994 as a member of the species P. azotofixans (formerly Bacillus azotofixans Seldin et al.) Ash et al. 1994. Int J Syst Bacteriol 47, 569-572.

Seldin, L., van Elsas, J. D. \& Penido, E. G. C. (1984). Bacillus azotofixans sp. nov., a nitrogen-fixing species from Brazilian soils and grass roots. Int J Syst Bacteriol 34, 451-456.

Skerman, V. B. D., McGowan, V. \& Sneath, P. H. A. (1980). Approved lists of bacterial names. Int J Syst Bacteriol 30, 225-420. 